\title{
Determinant Of Sharia Bank Indonesia Rate With Financing And Deposit In Indonesian Islamic Banking Asset
}

\author{
Roikhan Mochamad Aziz, Adit \\ \{roikhan.ma@uinjkt.ac.id, hshira.dyn@gmail.com
}

UIN Jakarta, Shira Institute

\begin{abstract}
This study aims to analyze the effect of bank certificates of Indonesia sharia (SBIS), financing to deposit ratio (FDR), and non-performing financing (NPF) against assets of Islamic Banking in Indonesia. The data used in this study are monthly time series data from the period from 2009 until 2013, published by Bank Indonesia of Indonesian Financial Statistics Report. The method of analysis used in this study is the Ordinary Least Square (OLS). The results of this study indicate that the variable certificates Indonesia sharia banks ((5.296593 and 0.0000), and financing to deposit ratio (5.512164 and 0.0000) had significant positive influence on Islamic banking assets in Indonesia. While non-performing financing variables (15.78500 and 0.0000$)$ had significant negative towards Islamic banking assets in Indonesia.
\end{abstract}

Keywords: SBIS, FDR, NPF, Asset, OLS

\section{Introduction}

\subsection{Background}

The establishment of Bank Muamalat Indonesia (BMI), in 1992, marked the beginning of the existence of Islamic banks in Indonesia. Law No. 10 of 1998 on banking which is a revision of Law No. 7 of 1992 was published. The law laid the groundwork for the development of a dual banking system, namely a banking system that allows banks with a profit sharing system (Sharia banks) to operate and banks operating with the interest system (Conventional Banks). Therefore, provided the broadest opportunity for the group to set up a bank that conducts general activities to open a branch office specializing in performing shariabased activities. Stronger are the efforts to grow banks with profit-sharing schemes. It is demonstrated by the public's increasing desire to access banking services using the principles of sharia.

The crisis that has hit the Indonesian banking world since 1997 has made everyone aware that banking with a conventional system is not the only reliable system, but there is another more resilient banking system, because it implements the principles of justice and openness, namely Islamic banking. Although there was only one Islamic banking financial institution at that time, it was understood by many circles that the adopted structure could respond to the challenges of the 1997-1998 crisis. Since then, Muslim and non-Muslim communities have become known for the Islamic banking that was born from the Rahim of Muslims. So that many conventional banks today have special Islamic bank units (Ulfah, 2008).

Islamic banking follows the concept of income sharing and risk (benefit and share of losses) in carrying out its operating activities. Islamic banks have an significant role within the 


\section{Kresna Social Science and Humanities Research}

Proceedings of the International Conference On Ummah:

Digital Innovation, Humanities And Economy (ICU: DIHEc) 2020

https:/doi.org/10.30874/ksshr.4

economy as part of the national banking system. The role of Islamic Banking in the economic activities of Indonesia is not much different from conventional banking (Sasmitasiwi, 2008).

If observed, the growth of Islamic banking in Indonesia is very remarkable compared to the first Islamic bank in Indonesia since the start of its establishment. This can be seen from several indicators, namely assets, Bank Indonesia Sharia Certificates (SBIS, Sertifikat Bank Indonesia Syariah), Financing to Deposit Ratio (FDR), and Non Performing Financing (NPF), based on Bank Indonesia data, each year increased the production of Islamic banking asset instruments for the period December 2009 to December 2013.

Sharia banking asset movement can not be isolated from many influencing measures, namely Bank Indonesia Syariah Certificates (SBIS), Financing to Deposit Ratio (FDR), and Non Performing Financing (NPF).

\subsection{Problem Formulation}

Problem formulation is a very important step, as this step will determine the direction of the research. In essence, the problem is to formulate questions whose answers will be pursued through research based on the circumstances of Sharia Bank Indonesia Certificate (SBIS), Financing to Deposit Ratio (FDR), and Sharia Banking Assets Non-Performing Financing (NPF) in Indonesia Period December 2009 - December 2013.

The discussion that will be conducted is formulated in the following questions, based on the current issue limitation:

1. How does Sharia Bank Indonesia Certificates (SBIS) influence sharia banking assets in Indonesia for the December 2009 - December 2013 period?

2. How does Financing to Deposit Ratio (FDR) affect sharia banking assets in Indonesia during the period December 2009 - December 2013?

3. What is the impact of Non Performing Financing (NPF) on sharia banking assets in the period from December 2009 - December 2013 in Indonesia?

4. How does Bank Indonesia Sharia Certificates (SBIS), Financing to Deposit Ratio (FDR) and Non-Performing Financing (NPF) affect Sharia Banking Assets in Indonesia simultaneously or jointly during the period December 2009-December 2013 ?

\subsection{Research Objectives}

The aim of this study is to express the researchers' desire to obtain answers to the research problems submitted based on the circumstances of the Sharia Bank Indonesia Certificate (SBIS), Financing to Deposit Ratio (FDR), and Non-Performing Financing (NPF) of Sharia Banking Assets in Indonesia December 2009 - December 2013 time.

Based on the description of the background of the problem, the objectives of this study are:

1. Analysis of the magnitude of Sharia Bank Indonesia Certificates (SBIS) influence on sharia banking assets in Indonesia, December 2009-December 2013.

2. Analysis of the magnitude of Financing to Deposit Ratio (FDR)'s impact on sharia banking assets in Indonesia, December 2009-December 2013.

3. Analyzing the size of the Non-Performing Financing (NPF) impact on sharia banking assets in Indonesia, December 2009-December 2013.

4. Analyzing the magnitude of Sharia Bank Indonesia Certificates (SBIS), Financing to Deposit Ratio (FDR), and Non-Performing Financing (NPF) effect on Sharia Banking Assets in Indonesia, December 2009-December 2013.

\subsection{Research Benefits}

Research's benefits include exploring the causes, explanations and effects of those situations. The advantages of the Islamic Banking Assets research and the variables that affect them are as follows:

1. For The Government

As one of the government's references in determining the Indonesian economy's policies or operational strategies relating to fund raising, especially as regards fund raising based on the sharia system.

2. For Sharia Bank

For Islamic Banking and Bank Indonesia as a material for comparison and consideration 


\section{Kresna Social Science and Humanities Research}

Proceedings of the International Conference On Ummah:

Digital Innovation, Humanities And Economy (ICU: DIHEc) 2020

https:/doi.org/10.30874/ksshr.4

in deciding policies or strategies to boost the efficiency of Islamic banks in order to increase the assets of Islamic banks.

3. For The Writer

Can provide insight or knowledge about the pattern of relationships between Bank Indonesia Sharia Certificates (SBIS), Financing to Deposit Ratio (FDR), and Non Performing Financing (NPF) on Sharia Banking Assets in Indonesia for the period December 2009 - December 2013.

4. For Customers and Investor

The findings of this study are expected to provide insight and knowledge when selecting goods from Islamic Banks. So, consumers and investors get a idea of how they will profit from the banking conditions.

5. For Academic Readers

In the banking sector, it is expected to be able to broaden horizons, particularly Islamic banking in this regard in relation to Islamic banking assets.

\section{Literature Review}

\subsection{Bank Indonesia Sharia Certificate}

a. Bank Indonesia Sharia Certificate (SBIS) Definition

According to Arifin (2009: 198) Bank Indonesia Sharia Certificate (SBIS, Sertifikat Bank Indonesia Syariah) is a certificate issued by Bank Indonesia made in the form of sharia-based monetary regulation and is one of the efforts to overcome if excess liquidity exists in Islamic banks. Based on Bank Indonesia Regulation No 10/11/PBI/2008 on Bank Indonesia Syariah Certificates (SBIS), the definition of SBIS is short-term sharia securities issued by Bank Indonesia in rupiah currency (www.wikipedia.org).

b. Relationship of Bank Indonesia Sharia Certificates (SBIS) to Assets

According to the research results of Hidayah (2008: 82) the variable SBI is positively linked to the variable of the properties. If SBI increases, an increase in assets will occur. Conversely, assets would also fall if SBI decreases. If there is a one-unit increase in SBI, assets will grow by 0.169 per cent.

\subsection{Financing to Deposit Ratio ( FDR )}

a. Financing to Deposit Ratio (FDR) Definition

Financing to Deposit Ratio (FDR) is a ratio used to calculate a bank's liquidity in repaying depositors' deposits by depending on funding given as a source of liquidity, that is, by dividing the amount of funding received by banks.

b. Relationship of Financing to Deposit Ratio (FDR) to Assets

The FDR has a large negative value, based on the model's estimation performance. That definitely indicates a negative relationship with an increase in the FDR ratio in Indonesia with the growth of Islamic banking assets. If the rise in the FDR ratio increases by 1 percent while

other variables (ceteris paribus) are considered stable, the growth of Islamic banking assets will decrease. This condition was also confirmed by the results of the t-test that showed that the fall in FDR had a major impact on the growth of Islamic banking assets. Any changes to the FDR will also cause changes in Islamic banking asset growth. The reason is that if there is an rise in FDR, then the bank's liquidity will decrease so that the number of bank assets will decrease and the total assets will decrease too.

\subsection{Non Performing Financing (NPF)}

a. Non Performing Financing (NPF) Definition

Problematic financing means financing which in its implementation has not reached or fulfilled the desired target of the bank such as: principal repayment or profit sharing that is problematic, financing that has the possibility of risk arising in the future for the bank, financing including special attention, doubtful and loss groups and smooth class which could potentially result in arrears in return (Veithzal, 2007).

b. Relationship of Non Performing Financing (NPF) to Assets

According to Dea Naufal Kharisma (2011: 9), the individual profitability NPF variable generates a t-test value of $0.516>0.05$, meaning that non-performing financing has a major effect on Islamic banking assets and a negative direction, meaning that there are less rates of non-performing financing resulting in lower profitability. Because in fact, what dominates Islamic banks' operational activities is the principle of buying and selling (murabahah), while 


\section{Kresna Social Science and Humanities Research}

Proceedings of the International Conference On Ummah:

Digital Innovation, Humanities And Economy (ICU: DIHEc) 2020

https:/doi.org/10.30874/ksshr.4

the profit-sharing principle is what characterizes Islamic banks. This is due to Islamic banks' insufficient precautionary principle, such that it is deemed risky if too much profit-sharing financing is spread.

\section{Research Method}

In this analysis the authors concentrate on the dependent variable, Islamic Banking Assets and the independent variable based on Bank Indonesia Sharia Certificates (SBIS), Financing to Deposit Ratio (FDR), and Non Performing Financing (NPF). The purpose of this study is to investigate the relationship of influence between two variables, namely independent variables (SBIS, FDR, NPF) and the dependent variable (assets).

The operational data used in this analysis utilizes data from time series. All data is published by Bank Indonesia on a monthly basis, including the period from December 2009 to December 2013, as well as from other related sources.

In this study to determine the analysis of the influence of Bank Indonesia Sharia Certificates (SBIS), Financing to Deposit Ratio (FDR), and Non Performing Financing (NPF) on Sharia Banking Assets in Indonesia, using quantitative data methods, namely where the data used in research in the form of numbers using the Ordinary Least Square analysis tool used to achieve minimum deviations or errors by using multiple regression analysis that is used more than two independent variables.

According to Ajija (2011: 23) Ordinary Least Square is an estimation tool which is commonly used to estimate the sample regression function of the population. Analysis of data will be carried out using a computer application, Excel 2010 program and Eviews program 6. In this study the data used is Differentiation data (D) all the data from the research variable is logged because the data units are different for the inclusion of data from these variables, and as a solution unknown equation is a set of other variables. The relation between the variables of assets and the variables DPK, SBIS, FDR, and NPF is formulated as follows:

While the econometrics model is written as:

$$
\mathrm{Y}=\mathrm{f}(\mathrm{X} 1, \mathrm{X} 2, \mathrm{X} 3, \mathrm{e})
$$

$\mathrm{Y}=\beta_{0}+\beta_{1} \mathrm{X}_{1}+\beta_{2} \mathrm{X}_{2}+\beta_{3} \mathrm{X}_{3} \mathrm{e}$
$\mathrm{ASET}=\beta_{0}+\beta_{1} \mathrm{SBIS}+\beta_{2} \mathrm{FDR}+\beta_{3} \mathrm{NPF}$ e
LN_ASET $=\beta_{0}+\beta_{1} \mathrm{LN} \_\mathrm{SBIS}+\beta_{2} \mathrm{FDR}+\beta_{3} \mathrm{NPF}$ e

W

here

$\beta$

0

$=$ Constanta

$\beta 1, \beta 2, \beta 3=$ Regression coefficients of each variable that affects assets

LN_ASET $=$ Asset log

LN_SBIS = Bank Indonesia Sharia Certificate log

FDR = Financing to Deposit Ratio

NPF $\quad=$ Non Performing Financing

$\mathrm{e} \quad=$ Error Terms (variables outside the model but do not affect the dependent variable).

Sampling in this study was done by purposeful sampling or sampling of judgments, which is the method of selecting samples based on considerations based on a coverage strategy, where information is obtained with certain considerations.

The sample in this analysis is a portion of assets in Indonesia's Sharia Banking for the period December 2009-December 2013. The sample selected is Bank Indonesia Sharia Certificate (SBIS), Deposit Ratio Financing (FDR), and Non Performing Financing (NPF).

The methods used in data collection to conduct this research are as follows:

1. Field Research 


\section{Kresna Social Science and Humanities Research}

Proceedings of the International Conference On Ummah:

Digital Innovation, Humanities And Economy (ICU: DIHEc) 2020

https:/doi.org/10.30874/ksshr.4

The data used in this analysis are secondary data collected through second-party processing or data reported to describe the symptoms of a disease, such as Bank Indonesia's (BI) reference centre.

2. Library Research

The data used in this analysis are data collected from reading literature, books, journals and the like, relevant to the aspects analyzed in an attempt to obtain reliable information.

3. Internet Research

Often, as science is still evolving, the reference books or literature that we have or borrow from the library are left behind for some time or expire. Therefore, in order to foresee this, the authors conducted research with technology that is also evolving, namely the internet so that the data collected are data that is in keeping with the times.

In this study, several statistical test methods were used by researchers including the Classic Inference Test consisting of the Normality Test, the Heteroscedasticity Test, the Multicollinearity Test, and the Autocorrelation test. Furthermore, researchers also used a statistical data test consisting of a partial test ( $\mathrm{t}$ test), the Fisher test ( $\mathrm{F}$ test) and the determination test coefficient.

In this study, the researchers determined that banking assets became the dependent variable ( $\mathrm{Y}$ variable) and the Independent Variable (Variable $\mathrm{X}$ ) was the Bank Indonesia Sharia Certificate, Financing to Deposit Ratio (FDR), Non-Peforming Financing (NPF).

\section{Discussion Result}

\subsection{Overview of Research Objects}

\section{History of the Development of Islamic Banks}

The Mit Ghamr Local Saving Bank activity in Egypt in 1963 marked a milestone in Islamic banking system growth. It was established in Egypt and was designed by Prof. Dr. Abdul Aziz Ahmad El Nagar with capital assistance from King Faisal, Saudi Arabia.

However, the Myt-Ghamr Islamic Bank was closed in 1967, due to political problems. Then in 1971 the Islamic bank was successfully re-established in Egypt under the name Nasser Social Bank, its main aim being more social than economic. The first private Islamic bank was the Islamic Bank of Dubai, founded in 1975 by a group of Muslim businessmen from different countries. Two Islamic banks were founded in Egypt and Sudan in 1977, under the name Faysal Islamic Bank. And that year the Kuwaiti government established the Kuwaiti House of Finance. (Suryani, 2012). The first Islamic bank established by a private party was the Islamic Bank of Dubai, which was founded in 1975 by a group of Muslim businessmen from different countries. Islamic banking growth internationally started in December 1970 with a meeting of foreign ministers organized by the Islamic Conference Organization in Pakistan. During the event, Egypt proposed the creation of an International Islamic Trade Bank, and the formation of the Islamic Banks Federation. The proposal was finally accepted, after discussion among 18 Islamic countries. In 1975, the establishment of the Islamic Development Bank was discussed at a meeting of finance ministers organized by the Islamic Conference Organization in Saudi Arabia (Utama, 2018).

The second phase, the development period in 1976 through the early 1980s, was marked by the spread of banking from the Arab Gulf region to Asia (East) and then to Europe (West).

The time in which Islamic banking has advanced in the third stage is around 1983 up to the present. The Islamic Bank of Malaysia Berhad was founded in Malaysia in 1983, followed in 1985 by the establishment of the Financial Institution for investment repair companies (al rajhi) in Saudi Arabia and the Turkish Finance House in Turkey, Al-Barakah.

The early 1980s influenced Indonesia by the establishment of Islamic banks in Islamic countries. There has been a lot of debate about Islamic banks as pillars of the Islamic economy. In 1990 the new started.

\section{Development of Islamic Banks in Indonesia}

In Indonesia Bank Muamalat was the first Islamic bank founded in 1992. Although its growth is quite late in comparison with other Muslim countries, Islamic banking will continue to expand in Indonesia. If there was only one Islamic bank unit in Indonesia in 1992-1998 then the number had risen to three units in 1999. Both Islamic banks and conventional banks which opened Islamic business units had grown to 6 units in 2000. While the number of BPRS (Sharia Rural Banks) reached 86 units and will continue to expand. The number of Islamic banks will continue to increase in the coming years along with the entry of new players, the 


\section{Kresna Social Science and Humanities Research}

Proceedings of the International Conference On Ummah:

Digital Innovation, Humanities And Economy (ICU: DIHEc) 2020

https:/doi.org/10.30874/ksshr.4

rise in the number of existing Islamic bank branches, and the opening of Islamic windows or Islamic business units in conventional banks. (Muhith, 2017)

In Law No. 21/2008 several new legal bodies were created, among others concerning the spin-off of UUS from the Sharia Banking Committee, both voluntary and compulsory. There are a number of Bank Indonesia Regulations or PBI (Peraturan Bank Indonesia) that explicitly enforce the Sharia Banking provisions of Act No. 21 of 2008 and have been implemented to date including:

a. PBI No. 10/16/PBI/2008 on amendments to PBI No. 9/19/PBI/2007 on the Application of Sharia Principles in the Collection and Distribution of Funds and Sharia Bank Services.

b. PBI No. 10/17/PBI/2008 concerning Sharia Bank Products and Sharia Business Units.

c. PBI No.10 / 18 / PBI / 2008 concerning Financing Restructuring for Islamic Banks.

d. PBI No. 10/23/PBI/2008 on the second amendment to PBI No. 6/21/PBI/2004 on legislative reserves in rupiahs and foreign currencies for commercial banks performing sharia-based business activities.

e. PBI No. 10/24/PBI/2008 on the second amendment to PBI No. 8/21/PBI/2006 on Asset Quality Evaluation of Commercial Banks performing business operations based on Sharia principles.

f. PBI No. 10/32/PBI/2008 concerning Sharia Banking Committees.

g. PBI No. 11/3/PBI/2009 concerning Sharia Commercial Banks.

So in 2015, despite experiencing a slight slowdown, the Islamic banking industry in Indonesia showed progressive and progressive both in terms of quantity and quality. These developments include, the number of Sharia Commercial Banks, Sharia Business Units, Sharia Rural Banks, Office Networks, Properties, Asset Growth, Market Share, Fundraising, Financing and others, as shown in the following graph:

Table 1. Sharia Bank in Indonesia

\begin{tabular}{|l|l|l|l|l|l|l|l|}
\hline Hints & 2011 & 2012 & 2013 & 2014 & MAC2015 & JUN2015 & SEP2015 \\
\hline $\begin{array}{l}\text { SHARIA } \\
\text { COMMERCIAL } \\
\text { BANK }\end{array}$ & 11 & 11 & 11 & 12 & 12 & 12 & 12 \\
\hline $\begin{array}{l}\text { SHARIA } \\
\text { BUSINESS } \\
\text { UNIT }\end{array}$ & 24 & 24 & 23 & 22 & 22 & 22 & 22 \\
\hline $\begin{array}{l}\text { BPRS } \\
\text { NUMBER }\end{array}$ & 155 & 158 & 163 & 163 & 162 & 162 & 162 \\
\hline $\begin{array}{l}\text { OFFICE } \\
\text { NETWORK } \\
\text { BUS + UUS) }\end{array}$ & 10737 & 2262 & 2588 & 2517 & 2463 & 2488 & 2401 \\
\hline $\begin{array}{l}\text { ASSETS } \\
\text { (TRILLION) }\end{array}$ & 145.47 & 195.02 & 242.28 & 272.34 & 268.36 & 273.49 & 282.16 \\
\hline $\begin{array}{l}\text { FUNWOTH } \\
\text { (TRILLION) }\end{array}$ & $49 \%$ & $34 \%$ & $24 \%$ & $12.41 \%$ & $11.39 \%$ & $8.57 \%$ & $9.57 \%$ \\
\hline $\begin{array}{l}\text { SHARE } \\
\text { GURTET }\end{array}$ & $3.39 \%$ & $4.58 \%$ & $4.89 \%$ & $4.85 \%$ & $4.68 \%$ & $4.61 \%$ & $4.59 \%$ \\
\hline
\end{tabular}




\section{Kresna Social Science and Humanities Research}

Proceedings of the International Conference On Ummah:

Digital Innovation, Humanities And Economy (ICU: DIHEc) 2020

https:/doi.org/10.30874/ksshr.4

\begin{tabular}{|l|l|l|l|l|l|l|l|}
\hline $\begin{array}{l}\text { FINANCING } \\
\text { (TRILION) }\end{array}$ & 102.66 & 147.51 & 184.12 & 199.30 & 200.71 & 206.06 & 208.14 \\
\hline
\end{tabular}

Source: Faiz zaini, 2019

3. Development of Islamic Banking Assets

Graph 1. Development of Sharia Banking Assets in Indonesia, December 2009 -

December 2013

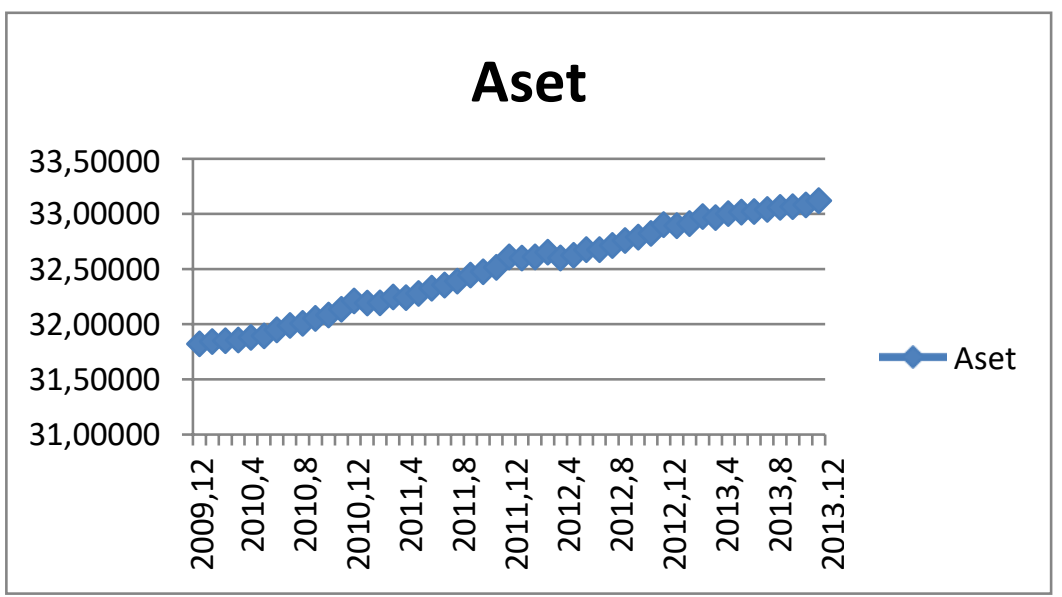

Source: Analysis, 2014

If seen, 2009 was a year full of challenges for Islamic banking due to rising world oil prices, and the financial crisis that started with problems with subprime mortgage has disrupted financial stability in both developed and developing nations. The financial system and economic growth of Indonesia also impact the shariadevelopment industry. Furthermore, with very good durability, the sharia development industry can face significant pressure so that it can improve the intermediate function of sharia banking which continues to operate effectively. Evidenced by the composition of Islamic banking assets dominated by real sector financing, market volumes increased to 66.090 billion rupiah at the end of 2009, with a share of 2,14 per cent of total national banking assets (Cleopatra, 2006).

Sharia banking assets rose by 48.6 per cent in 2013 , reaching 242.276 billion rupiah at the end of the year. This was triggered by the improved real-sector output and the growing growth of the Islamic banking industry. Furthermore, by beginning the expansion of the new Islamic Commercial Bank that was established in the previous year (Darna, 2006).

Table 2. Development of Total Sharia Banking Assets December 2014 - August 2016

\begin{tabular}{|lccc|c|c|}
\hline & Des & Des & Mar & Mei & Agustus \\
& 2014 & 2015 & 2016 & 2016 & 2016 \\
\hline Bank Umum Syariah & 204.961 & 213.423 & 213.061 & 211.358 & 216.766 \\
& & & & & \\
\hline Unit Usaha Syariah & 67.383 & 82.839 & 84.710 & 86.577 & 88.521 \\
\hline
\end{tabular}

Source: Otoritas Jasa Keuangan, 2016.

Based on the above table, it can be concluded that sharia banking asset creation is increasing, although it decreased in May 2016, and increased in August 2016. While the above table has developed from year to year, Islamic banking is still 


\section{Kresna Social Science and Humanities Research}

Proceedings of the International Conference On Ummah:

Digital Innovation, Humanities And Economy (ICU: DIHEc) 2020

considered slow to develop (Sofyan, 2016).

4. Development of Bank Indonesia Syariah Certificates (SBIS)

Graph 2. Development of Bank Indonesia Syariah Certificates (SBIS) in Indonesia for the period December 2009 - December 2013

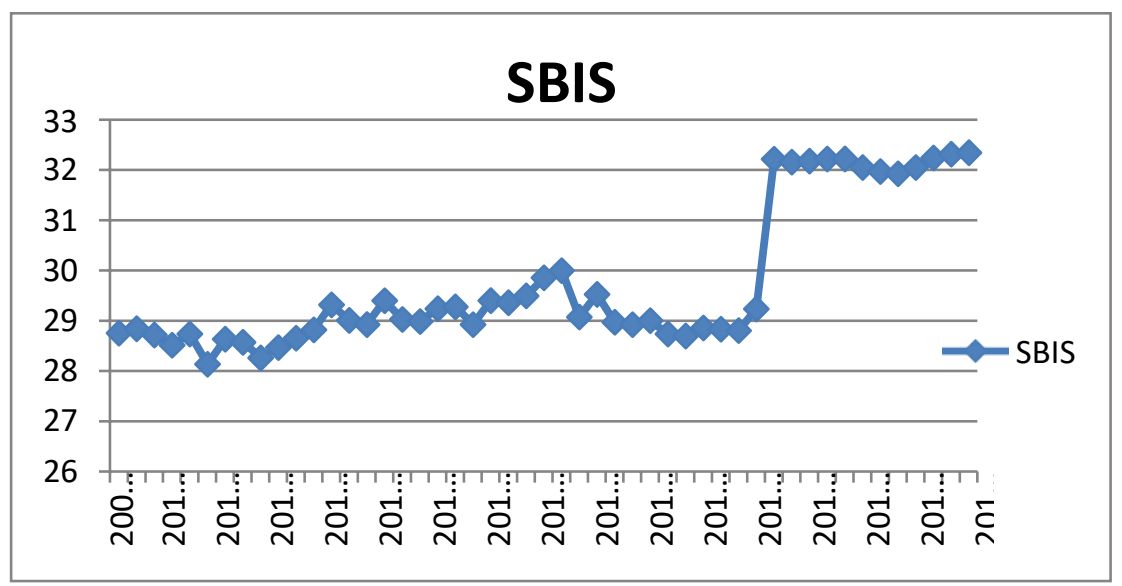

Source: Analysis, 2014

Based on the picture above, it can be seen that there was a significant increase in 2009 of Rp. 3.076 billion, in 2010 Rp. 5,408 billion, and in 2011 Rp. 9,244 billion. But it had decreased in 2012 amounting to Rp. 4,933 billion. But in 2013 there was a drastic increase of Rp. 111,689 billion. It is because SBIS has increased and Islamic banks can continue to want to channel their funds in asset form. Islamic banks may then agree on putting the excess funds in SBIS instruments. That states that government attention in the form of SWBI has a positive influence on Indonesia's Islamic banking assets.

5. Development of Financing to Deposit Ratio (FDR)

Graph 3. Development of Financing to Deposit Ratio (FDR) in Indonesia for the period December 2009 - December 2013

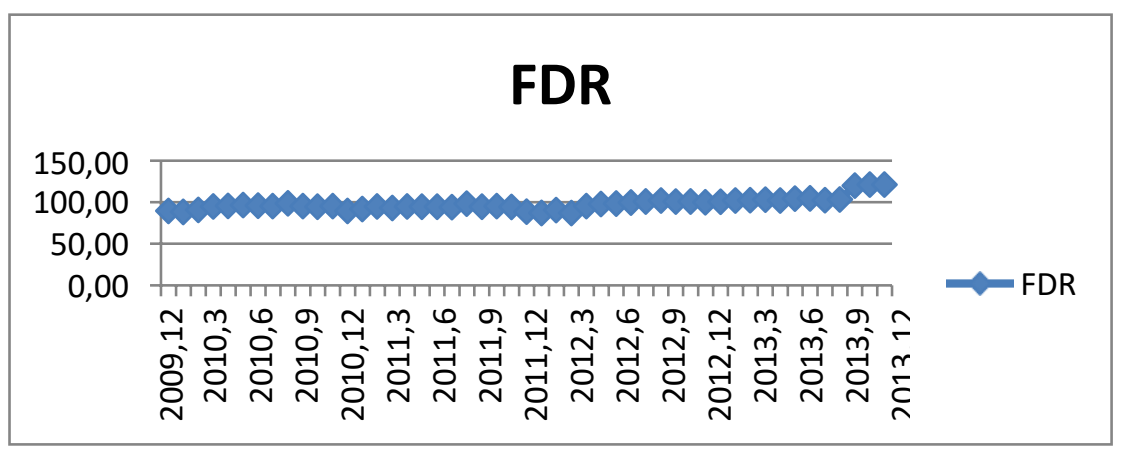

Source: Analysis, 2014

From the above photo, there was a substantial increase in $2009-2010,89.70 \%$ in 2009 and $89.67 \%$ in 2010 . But it fell by 88.94 per cent in 2011. And again rose by $100.00 \%$ in 2012 and by $121.46 \%$ in 2013. This is because FDR has rising, and there's less liquidity at banks. So the number of existing bank assets will be reduced and the total assets reduced as well. 


\section{Kresna Social Science and Humanities Research}

Proceedings of the International Conference On Ummah:

Digital Innovation, Humanities And Economy (ICU: DIHEc) 2020 https:/doi.org/10.30874/ksshr.4

6. Development of Non Performing Financing (NPF)

Graph 4. Development of Non Performing Financing (NPF) in Indonesia for the period December 2009 - December 2013

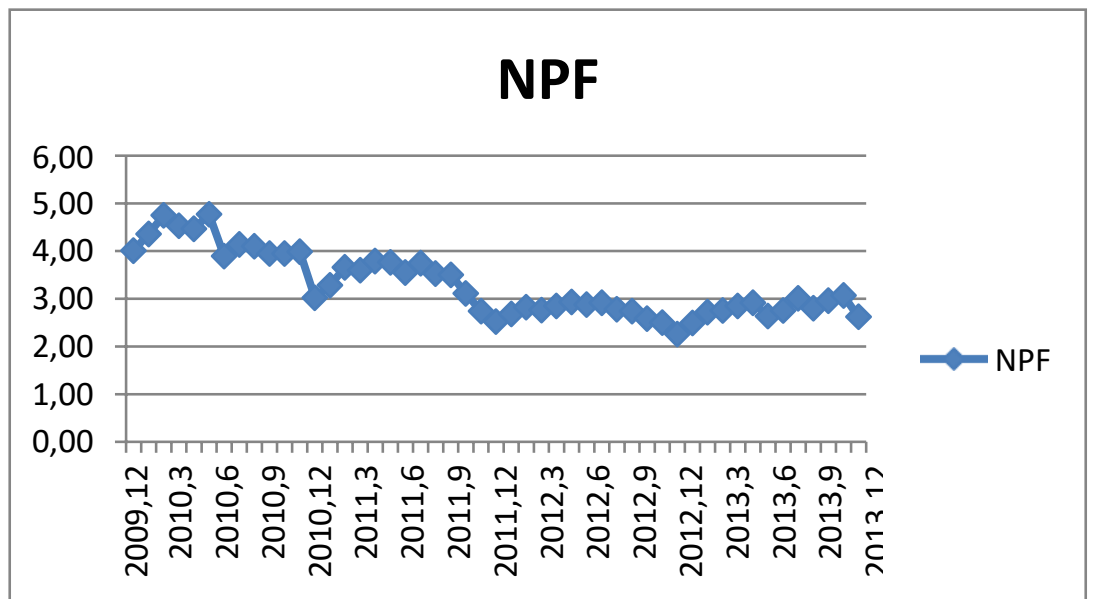

Source: Analysis, 2014

From the above picture, the largest non-current funding value was 4.01 percent in 2009. But in 2010 there was a decrease of 3.02 percent up to 2.52 percent in 2011. And in 2012 it decreased dramatically by $2.26 \%$. So that in 2013 an increase of $2.62 \%$. Based on this value, it can be explained that in nominal terms, NPF is very likely to increase along with the nominal increase in the amount of financing disbursed. This is due to the fact that every financing risk finds non-smooth financing, if you want to increase financing to the public, the financing is classified as non-smooth it is possible to increase. Bank Indonesia has therefore set a target in the form of a percentage ratio of non-current funding level categories with the goal that the bank will not hesitate to raise funding services to the public because what is considered is not a nominal but rather a small contrast.

Table 3. Development of NPF, BOPO and ROA on BNI Syariah Bank

\begin{tabular}{|l|l|l|l|}
\hline Year & NPF $(\%)$ & BOPO $(\%)$ & ROA ( \% ) \\
\hline 2013 & 1,13 & 88,11 & 1,37 \\
\hline 2014 & 1,04 & 89,80 & 1,27 \\
\hline 2015 & 1,46 & 89,63 & 1,43 \\
\hline 2016 & 1,64 & 87,67 & 1,44 \\
\hline
\end{tabular}

\begin{tabular}{|l|l|l|l|}
\hline 2017 & 1,50 & 87,62 & 1,31 \\
\hline \multicolumn{2}{|c|}{ Source: BNI Syariah Bank Report (March, 2018) } \\
\hline
\end{tabular}

Source: BNI Syariah Bank Report (March, 2018)

It can be seen that the NPF decreased in 2013-2014, while the ROA also decreased, to make reading easier, based on the Table. Although the NPF saw an rise in 2014-2016, the ROA also saw a rise in 2014-2016. In 2016-2017 the NPF experienced a decline but accompanied by a decrease in ROA in 2016-2017, this is contrary to Abdullah's theory (2005: 114), which notes that the Non Perfoming Finance (NPF) would be the lower the profitability and vice versa if the Non Perfoming Finance (NPF) is the lower the profitability will be (Supriyanto, 2019). 


\section{Kresna Social Science and Humanities Research}

Proceedings of the International Conference On Ummah:

Digital Innovation, Humanities And Economy (ICU: DIHEc) 2020 https:/doi.org/10.30874/ksshr.4

\subsection{Data Analysis and Discussion}

1. Classic Assumption Test a. Normality Test

Graph 5. Normality Test

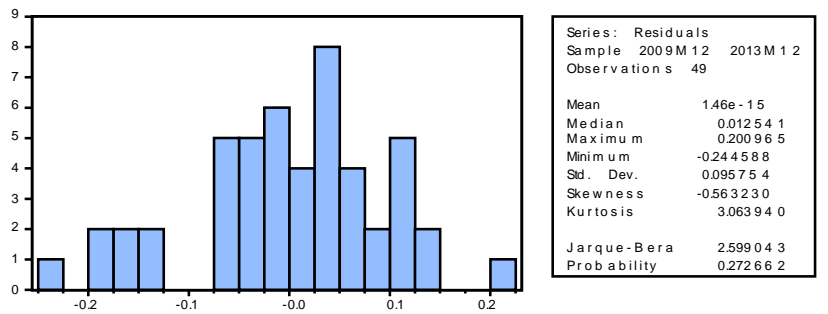

Source: Analysis, 2018

Based on graph 5 illustrates that the data in this study are normally distributed. It can be seen from the probability value of 0.272662 which is greater than the degree of confidence of $0.05(5 \%)$ and the Jarque-Bera value of 2.599043 is less than 2 so that it can be declared significant. According to Winarno (23: 2009) states that if the value of Jarque-Bera is less than 2 and Probability is more than $0.05(5 \%)$, the data can be said to be the results of the regression are normally distributed and H0 is accepted. If it is said to be normal, then the data produces an unbiased linear estimation or commonly called BLUE (Best Linear Unlock Estimator).

a. Multicollinearity Test

Table 4. Correlation Matrix Test Results

\begin{tabular}{|l|c|c|c|}
\hline \multicolumn{1}{|c|}{$\begin{array}{c}\text { Independent } \\
\text { Variable }\end{array}$} & LNSBIS & FDR & NPF \\
\hline LNSBIS & 1.000000 & 0.653701 & -0.534470 \\
\hline FDR & 0.653701 & 1.000000 & -0.350481 \\
\hline NPF & -0.534470 & -0.350481 & 1.000000 \\
\hline
\end{tabular}

Source: Analysis, 2018

Seen from table 4 above the correlation value of each independent variable is below or smaller than 0.8 so that it can be concluded that $\mathrm{H} 0$ is accepted, that the data is free from multicollinearity and the Ordinary Least Square (OLS) model performed can be said to be free from multicollinearity symptoms. So that it can proceed to the next test, the Heteroscedasticity test.

b. Heteroscedasticity Test

Table 5. White Heteroskedasticity Test Results

\begin{tabular}{|l|l|l|l|}
\hline F-Statistic & 0.862904 & Prob. F & 0.5652 \\
\hline Obs*R-Squared & 8.137097 & Prob. Chi Square & 0.5204 \\
\hline
\end{tabular}

Source: Analysis, 2018

From table 5 above it is known that the value of Obs * R2 is 8.137097 and the Chi-Square Probability of 0.5204 is greater than the confidence level of 0.05 (5\%) so that it can be concluded that the data is not heteroscedasticity or HO is accepted. 


\section{Kresna Social Science and Humanities Research}

Proceedings of the International Conference On Ummah:

Digital Innovation, Humanities And Economy (ICU: DIHEc) 2020

c. Autocorrelation Test https:/doi.org/10.30874/ksshr.4

Table 6. Lagrange Multiplier Test Results

\begin{tabular}{|l|l|l|l|}
\hline F-Statistic & 2.656991 & Prob. F & 0.0817 \\
\hline Obs*R-Squared & 5.38946 & Prob.Chi-Square & 0.0676 \\
\hline
\end{tabular}

Source: Analysis, 2018

From table 6 above it can be seen that the value of Obs * $\mathrm{R} 2$ is 5.38946 and the Chi-Square Probability value of 0.0676 is greater than the value of 0.05 , so H0 is accepted so that it can be concluded that the data do not have autocorrelation problems. This informs that the proposed OLS model can be said to be free from heteroscedasticity so that further testing can be continued.

2. Statistic Test

Table 7. Metode Ordinary Least Square (OLS) Regression Result

\begin{tabular}{|l|l|l|l|}
\hline Variabel & Koefisien & t-Statistik & Probabilitas \\
\hline C & 30.14231 & 74.81307 & 0.0000 \\
\hline LNSBIS & 0.077583 & 5.296593 & 0.0000 \\
\hline FDR & 0.013822 & 5.512164 & 0.0000 \\
\hline NPF & -0.397599 & -15.78500 & 0.0000 \\
\hline F-Statistik & 262.0236 & & \\
Probabilitas (F-stat) & 0.000000 & & \\
Adjusted R-squared & 0.942243 & & \\
Durbin-Watson stat & 1.241820 & & \\
\hline
\end{tabular}

Source: Analysis, 2018

From the table above, it can be arranged multiple linear regression equations as follows:

LNASET $=30.14231+0.077583$ LNSBIS +0.013822 FDR $-0.397599 \mathrm{NPF}$

a. Partial Test (t-test)

1. Effect of t-statistics for Bank Indonesia Syariah Certificates (SBIS) on assets.

Based on table 4.5 the t-test results obtained are 5.296593 with a significant level of 0.0000 . Because the significant level is less than 0.05, SBIS partially has a positive and significant effect on assets.

2. Effect of t-statistics for Financing to Deposit Ratio (FDR) on assets.

Based on table 4.5 the t-test results obtained are 5.512164 with a significant level of 0.0000 . Because the significant level is less than 0.05 , partially FDR has a significantly positive effect on assets.

3. Effect of t-statistics for Non-Performing Financing (NPF) on assets.

Based on table 4.5 the $t$-test results obtained of -15.78500 with a significant level of 0.0000. Because the significant level is less than 0.05, the NPF partially has a significantly negative effect on assets.

b. Fisher Test (F Test)

The F-statistic result is, based on table 4.5, 262.0236 with a probability value (F-stat) of 0.000000. Because the probability (F-stat) is less than 0.05, it can be concluded that the assets are significantly affected by SBIS, FDR, and NPF together.

c. Coefficient of Determination

Based on the regression results in table 4.5, it can be shown that the Modified R-Squared value of 0.942243 shows that the variance of the dependent variable (assets) can be explained together by the variance of 94.2 percent of the independent variables (SBIS, FDR, and NPF). Although other variables outside the variables 


\section{Kresna Social Science and Humanities Research}

Proceedings of the International Conference On Ummah:

Digital Innovation, Humanities And Economy (ICU: DIHEc) 2020 https:/doi.org/10.30874/ksshr.4

analyzed clarify the remaining 5.8 per cent.

\section{Conclusion}

The results of the multiple regression analysis showed that of the three variables, namely Bank Indonesia Sharia Certificate (SBIS), Financing to Deposit Ratio (FDR), and NonPerforming Financing (NPF) on sharia banking assets, which only had a major positive impact on the SBIS variable. Where SBIS has positive impact on properties. In practice, distributing Islamic bank funds to the real sector requires time that is often not as short as collecting funds, so Islamic banks may decide to position excess funds in SBIS instruments, even if they offer only incentives but are very secure and flexible. It is proven that if an Islamic bank has excess funds from a third party, then an Islamic bank has the option of channeling for funding or depositing the funds into an Islamic monetary instrument, SBIS, which functions to see Islamic banking liquidity. The relationship between SBIS and assets is significantly positive. This is because the instrument has not played an optimum function because the idle cash (funds that are unused) is lost by the sharia at the end of the year and then imposed on the SWBI by wanting and anticipating high income, which should be channeled to the real sector, but because it considers the risks that have arisen, then the bank puts on SWBI.

The Financing to Deposit Ratio (FDR) variable has an significant positive impact on Islamic banking assets. This means that the findings showing that the rise in FDR has a direct impact on the growth of Islamic banking assets also reinforce this situation. Any changes to the FDR would also trigger shifts in the assets of Islamic Banking. This is due to the high FDR, which suggests a high degree of funding from Islamic banks. The financing provided by Islamic banks is Islamic banking assets according to Banoon and Malik (2007). And the more funding is provided by Islamic banks would impact the amount of growth of the properties. According to Ginanjar (2003), the large amount of funding disbursed would have a positive effect on asset growth in the next century, as financing would later produce income that will affect asset development.

Then the vector Non Performing Financing (NPF) has a major and negative impact on the assets of Islamic Banking. This means the less the Non-performing Financing (NPF) rates in Islamic banks would increase Islamic banks' assets. It is because non-performing lending or a bit of bad credit will minimize costs, and it won't have the potential for bank losses later. The less this ratio, the higher the standard of bank funding makes the amount of non-current

funding to be less and thus Islamic banks do not have to suffer any losses in their operating operations so that it affects the increase in assets received by Islamic banks.

\section{References}

[1] Cleopatra, Y. P. Faktor-Faktor Yang Mempengaruhi Pertumbuhan Proporsi Aset Perbankan Syariah di Indonesia. Jurnal (dipulikasikan) Fakultas Ekonomi dan Bisnis, Universitas Indonesia, Program Studi Timur Tengah dan Islam. 2006.

[2] Darna. Sensitifitas Aset dan Dana Pihak Ketiga (DPK) Perbankan Syariah Terhadap Volatilitas Tingkat Suku Bunga (SBI) dan Nilai Tukar Rupiah Serta Pengaruh Fatwa MUI tentang Pengharaman Bunga Bank. Jurnal (dipulikasikan), Fakultas Ekonomi, Universitas Indonesia. 2006.

[3] Faiz zaini, D. M. The Prospect Of Sharia Banking In Indonesia Opportunities,. International Journal of Business Management and Economic Review, 6. 2019.

[4] Muhith, A. Sejarah Perbankan Syariah. Attanwir: Jurnal Kajian Keislaman dan Pendidikan. 2017.

[5] Sasmitasiwi, B. d. Prediksi Pertumbuhan Perbankan Syariah di Indonesia. Jurnal (dipublikasikan) Fakultas Ekonomi, Universitas Gajah Mada. 2008.

[6] Sofyan, S. Perkembangan Perbankan Syariah Di Indonesia. Bilancia: Jurnal Studi Ilmu Syariah dan Hukum, 91-112. 2016.

[7] Supriyanto, D. Analysis of Non Performing Financing (NPF) and Operational Efficiency Ratio (BOPO) on Return on Asset (ROA). Banking \& Management Review, 1123-1136. 2019. 


\section{Kresna Social Science and Humanities Research}

Proceedings of the International Conference On Ummah:

Digital Innovation, Humanities And Economy (ICU: DIHEc) 2020

[8] Suryani, S. Sistem Perbankan Islam di Indonesia: Sejarah dan Prospek Pengembangan.

Muqtasid: Jurnal Ekonomi dan Perbankan Syariah, 111-131. 2012.

[9] Ulfah, M.. Analisa Perkembangan Asset, Dana PihakKetiga (DPK) dan Pembiayaan Perbankan Syariah di Indonesia. Jurnal (dipublikasikan) Universitas Gunadarma. 2008.

[10] Utama, A. S. History and Development of Islamic Banking Regulations in the National Legal System of Indonesia. Al-'Adalah, 27-50. 2018. 